\title{
Competition among small colonies of Agaricia: the importance of size asymmetry in determining competitive outcome
}

\author{
Carla Zilberberg, Peter J. Edmunds* \\ Department of Biology, California State University, 1811 Nordhoff Street, Northridge, California 91330-8303, USA
}

\begin{abstract}
Scleractinian corals may experience competition at early life history stages, particularly where aggregated settlement decreases the space available for growth. The outcome of such interactions can affect post recruitment success and the relative abundance of coral species. The purpose of this study was to determine the importance of competition among small colonies $(\leq 4 \mathrm{~cm}$ diameter) of Agaricia on shallow ( $\leq 10 \mathrm{~m}$ depth) reefs in St. John (US Virgin Islands) and Jamaica. The association between the density of small Agaricia and the frequency of congeneric encounters was examined, together with the relationship between density of Agaricia and reef rugosity (topographic complexity). Rugosity was analyzed because it indirectly affects competitive interactions by providing cryptic habitats that promote aggregated settlement and coral-coral interactions. To test one possible mechanism determining the outcome of such interactions, the relationship between size asymmetry of competing colonies and competitive outcome was assessed. The results demonstrate that competition among small Agaricia is common, particularly where aggregated settlement is favored by high topographic complexity. In other words, competitive interactions among small Agaricia are affected by both physical (e.g. topographic complexity) and biological (e.g., settlement patterns) factors. The outcome of such interactions is influenced by the difference in size of competing colonies, with dominant colonies generally being larger than subordinate colonies. Further research is required to identify the mechanistic basis of dominance, but currently the most likely hypotheses are that large colonies are dominant because they have greater energy resources than small colonies, or intrinsically faster growth rates. The high frequency of competition among Agaricia colonies in St. John and Jamaica suggests that further studies of congeneric competition within the Scleractinia may prove valuable in understanding the population biology of this taxon.
\end{abstract}

KEY WORDS: Competition · Size asymmetry $\cdot$ Scleractinians $\cdot$ Small $\cdot$ Agaricia

Resale or republication not permitted without written consent of the publisher

\section{INTRODUCTION}

Space often is a limiting resource for sessile marine invertebrates in hard-substratum, benthic communities (Jackson \& Buss 1975, Sebens 1982). In the absence of major disturbances or predation, competition for this resource (i.e., space) may play an important role in shaping community structure (Jackson \& Buss 1975, Connell 1978). This is particularly important for sessile, clonal taxa that often encounter other

${ }^{*}$ Corresponding author. E-mail: peter.edmunds@csun.edu organisms when they spread laterally through asexual proliferation (Sebens 1982, Buss 1986). Coral reefs provide a particularly good example of an ecosystem dominated by sessile, clonal taxa (scleractinians), and where spatial competition has a strong effect on organism distribution (Sheppard 1979, 1980). Thus, the competitive ability of corals likely influences their population dynamics and individual fitness (Lang 1973, Connell 1978, Sheppard 1980).

Given the role of competition in determining coral community structure (Lang 1973, Sheppard 1979, 1980), mechanisms of interspecific aggression among scleractinians have been studied extensively (Lang \& 
Chornesky 1990). Interspecific dominance patterns are a result of a variety of agonistic mechanisms, where dominance typically is genetically determined, based on the type, relative abundance and/or delivery mode of the agonistic structures or agents (Chornesky 1983, Lang \& Chornesky 1990). In contrast, intraspecific competitors cannot rely on species-level differences in agonistic structures to determine competitive outcome (Hidaka \& Yamazato 1984). Instead, the outcome of intraspecific encounters depends on the vagaries of chance events (i.e., storms, Connell 1978, Hughes 1989), or other factors such as the genotypic identity of individual colonies (Ayre \& Grosberg 1995), water flow (Genin et al. 1994), or size asymmetry of competing colonies (Rinkevich \& Loya 1983). Colonies of some species attain dominance in intraspecific interactions by growing large (Rinkevich \& Loya 1983). For example, the overgrowth of small colonies by large colonies may reflect the energetic cost of competition (Padilla et al. 1996), and the greater ability of large colonies to meet this cost (Rinkevich \& Loya 1983, Padilla et al. 1996). The reduction in growth rates of competing colonies further suggests that competition is energetically costly (Rinkevich \& Loya 1983, Padilla et al. 1996). Thus, assuming excess energy can be translocated across coral colonies, and used for competition (Oren et al. 1997), large colonies should win competitive encounters with smaller colonies (Rinkevich \& Loya 1983, Padilla et al. 1996).

Most studies of coral competition have focused on adult colonies ( $>10 \mathrm{~cm}$ diameter; Lang 1973, Chornesky 1983, Rinkevich \& Loya 1983) that, by definition, are sexually mature (Harrison \& Wallace 1990). This is because adult corals typically are conspicuous members of the reef community, and fulfill a diversity of ecologically important functions (Buss \& Jackson 1979). Few studies however, have focused on competitive interactions among small corals (most of which also are young; Bak \& Engel 1979), despite strong evidence for aggregated settlement favoring competitive encounters in this size class (Morse et al. 1988, Smith 1997). Because small corals have important effects on coral demographics (Hughes \& Jackson 1985, Bak \& Meesters 1999), the paucity of information about competition among them makes it difficult to fully understand the biological processes affecting the population biology of corals (Hughes \& Jackson 1985, Dunstan \& Johnson 1998).

The ecological importance of competition (if any) among small corals will be accentuated under conditions favoring such encounters. One such scenario may occur on reefs with high coral cover and high recruitment, as in the tropical west Pacific (Sheppard 1980, Wallace 1985, Connell et al. 1997). Similar conditions could also occur when coral larvae settle adjacent to one another in confined locations, such as cracks and crevices (Bak \& Engel 1979, Morse et al. 1988, Smith 1997). Aggregated larval settlement (Lewis 1974, Goreau et al. 1981, Smith 1997) will further accentuate intraspecific encounters in such locations. The importance of aggregated settlement in promoting competition should increase in topographically complex communities (Carleton \& Sammarco 1987), where spatial refuges and cryptic habitats are common (Menge 1976). Aggregated settlement is particularly common in corals with a brooding life history strategy, which often produce larvae with limited dispersal and a tendency for philopatric settlement (Carlon \& Olson 1993). Once newly settled conspecifics encounter one another, two or more colonies will fuse (Hidaka 1985), or competition will result in a distinct winner and loser emerging (Lang \& Chornesky 1990).

The brooding Caribbean coral Agaricia provides a tractable system to study competition among small corals. This is because Agaricia is one of the most common genera encountered during surveys of coral recruitment (Bak \& Engel 1979, Hughes 1985, Smith 1997, Edmunds 2000, Hughes \& Tanner 2000), and typically is aggregated in cryptic locations (Lewis 1974, Rogers et al. 1984, Smith 1997) where congeneric interactions are common. As a result, competition among Agaricia may have an important effect on the density and distribution of colonies, as well as possibly the genetic structure of adult populations. For example, competition among Agaricia at early life history stages could result in selection for competitively superior genotypes (Snell 1979, Yund 1991).

The purpose of this study was to determine the importance of competition among small (young) Agaricia, and to test one possible determinant of competitive outcome. Agaricia were not separated into A. agaricites and $A$. humilis, both of which are common in shallow water (Hughes 1985, Van Moorsel 1985, Hughes \& Tanner 2000), because they have similar morphologies (especially when small) that cannot be distinguished reliably in the field (Van Moorsel 1983, 1985). An analysis at the genus level is unlikely to affect the outcome of this study, since only 2 species are involved, and both have comparable 'weedy' life history strategies (Hughes 1985, Hughes \& Tanner 2000). Moreover, both species have similar mechanisms of interspecific aggression (i.e., sweeper tentacles), at least as adult colonies (Chornesky 1983, C. Zilberberg pers. obs.). To address the importance of competition among Agaricia, first we quantified the frequency of congeneric encounters as well as encounters with other taxa (benthic algae, scleractinians [other than Agaricia], and other invertebrates). Using the relative frequencies of encounters as a measure of importance, we determined whether competition among Agaricia was equally im- 
portant for large and small colonies, and whether it was affected by the physical structure of the reef (i.e. topographic complexity). Second, to gain insights into possible mechanisms determining competitive outcome among Agaricia, we tested whether the outcome was related to the size asymmetry of competing colonies (i.e., the relative difference in sizes).

\section{MATERIALS AND METHODS}

Study sites. Competition among small Agaricia was studied on the south-facing, shallow (6 to $10 \mathrm{~m}$ depth) reefs of Great Lameshur Bay, St. John (US Virgin Islands), and at Dairy Bull reef on the north coast of Jamaica (2 $\mathrm{km}$ east of Discovery Bay). Maps of the study sites are provided in Edmunds (2000) and Edmunds \& Carpenter (2001). All research was completed during 1998 and 1999, and surveys were carried out on 2 islands in order to strengthen the conclusions and their application to a larger spatial scale. The study reefs in St. John were located at Yawzi Point and Tektite cliffs (at 6 to $7 \mathrm{~m}$ depth), and had a high percentage cover of algal turf and macroalgae, and a low cover of scleractinian corals (Table 1). At the study location on Dairy Bull reef (8 to $10 \mathrm{~m}$ depth), the percent cover of algal turf and macroalgae also was high, but the scleractinian cover was 5-fold greater than in St. John (Table 1). Near-by reefs had $<5 \%$ coral cover and, therefore, Dairy Bull was not typical of Jamaican reefs (Edmunds \& Bruno 1996, Edmunds 2000, Edmunds \& Carpenter 2001).

Frequency of congeneric interactions. The relative importance of competition among Agaricia was determined using transects $\left(\mathrm{N}=4\right.$ to 6 site $\left.^{-1}\right)$ placed at random locations, parallel to the shore on reefs in St. John and Jamaica. All colonies (regardless of size) of Agaricia within $1 \mathrm{~m}$ of either side of the transect were scored for competitive interactions. Competing organisms were categorized as algae (including both macroalgae [>5 mm high] and algal turf $[<5 \mathrm{~mm}$ high], sensu Steneck \& Watling 1982), Agaricia, scleractinians (other than Agaricia), or other sessile invertebrates

Table 1. Percent cover (means \pm SE) of macroalgae, algal turf and scleractinians in St. John and Jamaica (at 6 to $10 \mathrm{~m}$ depth). Sample sizes in parentheses with quadrats as replicates, except for algal turf in St. John, where sites are replicates; algal turf and vacant hard substratum were combined in St. John. Data from published sources as follows: ${ }^{\mathrm{a}}=$ Edmunds \& Bruno 1996, ${ }^{\mathrm{b}}=$ Edmunds $2000,{ }^{c}=$ Edmunds \& Carpenter 2001

\begin{tabular}{|lccc|}
\hline Sites & Macroalgae & Algal turf & Scleractinians \\
\hline St. John & $17.0 \pm 3.0(17)^{\mathrm{b}}$ & $69.9 \pm 4.9(18)^{\mathrm{b}}$ & $5.0 \pm 1.5(17)^{\mathrm{b}}$ \\
Jamaica & $40.0 \pm 15.0(36)^{\mathrm{a}}$ & $52.6 \pm 5.4(20)^{\mathrm{c}}$ & $23.0 \pm 20.0(36)^{\mathrm{a}}$ \\
\hline
\end{tabular}

(e.g., sponges, tunicates and bryozoans). Scleractinians and invertebrates were quantified as broad taxonomic groups to underscore differences between coral-coral and other types of competitive encounters. Interactions were defined as physical contact between the margins of Agaricia colonies and other taxa (sensu Lang \& Chornesky 1990).

Interactions between Agaricia and algae only were scored when algae were the single source of contacts. When other taxa (i.e., not algae) also were in contact with Agaricia, then the other interaction was quantified. Although this approach has the potential to underestimate the frequency of interactions with algae, this bias was minimized by the occurrence of most Agaricia colonies within cracks and crevices where turf and macroalgal cover were minimal. Multiple contacts between Agaricia and taxa other than algae were infrequent in both St. John and Jamaica (C. Zilberberg pers. obs.) but, when observed, only the interaction with the longest perimeter of contact was scored.

To test the hypothesis that the frequency of congeneric competition in Agaricia varied with colony size, the number of congeneric interactions was compared among size classes. Sizes were assessed from the average of the maximum and minimum colony diameters, as determined with calipers $( \pm 0.1 \mathrm{~mm})$, and were pooled into 3 classes $(\leq 4 \mathrm{~cm}, 4.1-10 \mathrm{~cm}$ and $>10 \mathrm{~cm}$ diameter). These classes also separated young $(\leq 4 \mathrm{~cm})$ and adult ( $>10 \mathrm{~cm}$, sexually mature) colonies (Van Moorsel 1983, 1985); the medium size class $(4.1-10 \mathrm{~cm})$ contained colonies of ambiguous sexual maturity (Van Moorsel 1983, 1985). Although size and age in corals are poorly related due to partial mortality and fission (Hughes \& Jackson 1980), these factors rarely affect small corals that typically experience whole, rather than partial, mortality (Hughes \& Jackson 1985). Fusion between colonies is another potential factor contributing to the poor relationship between size and age, although it is most likely to occur immediately after settlement and becomes less common as colonies increase in size (Frank et al. 1997). Assuming that partial mortality and fusion are uncommon for Agaricia colonies $\leq 4 \mathrm{~cm}$ diameter, then corals in this size class are young ( 2 to 3 yr old; Bak \& Engel 1979, Van Moorsel 1983, Hughes \& Jackson 1985), and of sexual origin. Small colonies with the fractured surfaces that are characteristic of asexual reproduction (Highsmith 1982, Edmunds 2000) were not found.

Preliminary surveys revealed that the frequency of competitive interactions among small Agaricia was highest in cracks and crevices, where small colonies of this genus were most abun- 
dant (C. Zilberberg pers. obs.). To address the possibility that increase in availability of cryptic habitats would enhance opportunities for competitive encounters, surveys were expanded at Dairy Bull (which has areas of high and low relief) to examine the relationships among cryptic habitats, the density of Agaricia, and the frequency of congeneric interactions.

To determine whether the frequency of competitive encounters was related to Agaricia density, 22 quadrats $\left(0.25 \mathrm{~m}^{2}\right)$ were placed randomly along 2 transects at Dairy Bull (10 m depth), and used to quantify small ( $\leq 4 \mathrm{~cm}$ ) Agaricia and the number involved in congeneric competition. To determine whether the density of small Agaricia was related to availability of cryptic habitats, the topographic complexity ( $\mathrm{TC}_{\text {; }}$ Rogers et al. 1984) of the reef was measured. TC is a measure of rugosity, and here we assume that rugosity is positively correlated with the availability of cryptic microhabitats. TC was calculated by conforming a fine chain (with $15 \mathrm{~mm}$ links) to the reef within each quadrat, and dividing the length of the conformed chain by the width of the quadrat to provide a dimensionless index with a minimal value of 1 for a flat reef.

Relationship between colony size and competitive outcome. To determine whether the competitive outcome was associated with the relative size of the competing colonies, transects were placed parallel to shore at 6 to $10 \mathrm{~m}$ depth, and competing pairs of Agaricia were sampled for size and outcome (dominant or subordinate). The surveys were completed in Jamaica (4 transects) and St. John (6 transects), and the results pooled for statistical analysis. All pairs of colonies within $1 \mathrm{~m}$ of either side of the transects were surveyed, and only colonies $\leq 4 \mathrm{~cm}$ diameter were considered. Dominance was defined by overgrowth of the adjacent colony (the subordinate; Buss 1980) and the colony pair was excluded from the analysis if dominance could not be established by visual detection of colony overgrowth; a mean of $32 \pm 8 \%( \pm \mathrm{SD}, \mathrm{N}=2$ islands) of the colony pairs were excluded for this reason. Colony size was calculated as the average of the maximum and minimum diameters as measured with calipers $( \pm 0.1 \mathrm{~mm})$. Thus, each pair of colonies generated 2 dependent measures of size and outcome. To obtain independent measurements, competitive outcome and size asymmetry was expressed relative to 1 colony of each pair that was selected at random. Size asymmetry was calculated by subtracting the size of the rejected colony from the size of the selected colony.

Statistics. A G-test of independence was used to determine whether the frequency of interactions with 4 categories of competing organisms (algae, Agaricia, other scleractinians, and invertebrates) was dependent on site. Where the frequency of interactions differed between sites, unplanned tests with selected subsets of data were used to determine where the significant differences occurred (Sokal \& Rohlf 1995). A G-test of independence was also used to compare frequencies of congeneric interactions among size classes and between sites.

Pearson correlations were used to examine the relationships between density of Agaricia and both frequency of competition and TC. A logistic regression (independent variable = size asymmetry; dependent variable = outcome [dominant or subordinate]) was used to test the null hypothesis that the outcome of congeneric competition was independent of size asymmetry.

All statistical analyses were completed using Systat 5.2 (SPSS corp., Chicago, IL) except for the logistic regression, that was completed using JMP 3.2.2 (SAS corp., Cary, NC), and unplanned comparisons of the significant $G$-tests of independence that were carried out using BIOM-pc (Exeter corp., Setauket, NY).

\section{RESULTS}

\section{Frequency of congeneric interactions}

Agaricia were conspicuous members of the shallow coral reefs in St. John and Jamaica, although densities differed markedly between sites. In St. John, the mean density of Agaricia colonies was $0.8 \pm 1.2 \mathrm{~m}^{-2}( \pm \mathrm{SE}$, $\mathrm{N}=40$, P. J. Edmunds unpubl. data), and in Jamaica it was $67.7 \pm 6.1 \mathrm{~m}^{-2}( \pm \mathrm{SE} ; \mathrm{N}=21$; C. Zilberberg unpubl. data). However, the majority (>90\%) were interacting with other taxa at both sites, and therefore large num-

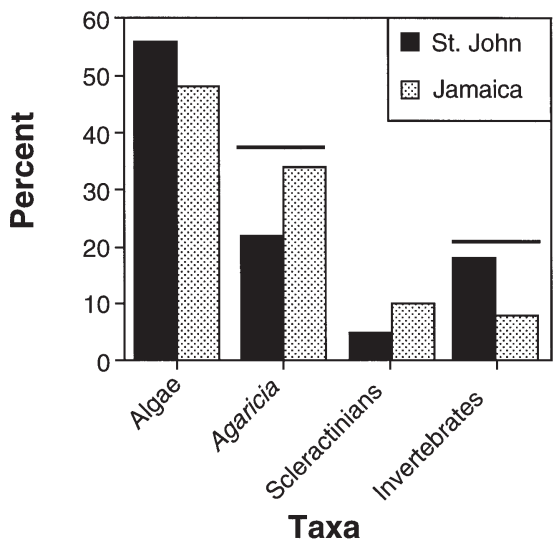

Fig. 1. Competitive interactions by taxon involving Agaricia in St. John $(\mathrm{N}=360)$ and Jamaica $(\mathrm{N}=402)$. Interactions are shown by taxon of competitor, and the values shown are the percentage of the total number of interactions. Horizontal bars indicate where unplanned comparisons demonstrated that significant differences occur (G-test, unplanned comparisons; $\mathrm{p} \leq 0.05$ ) 


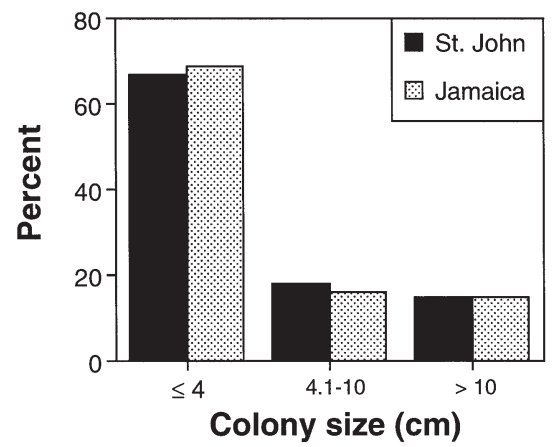

Fig. 2. Congeneric competition among colonies of Agaricia, separated by size class, for St. John $(\mathrm{N}=78)$ and Jamaica $(\mathrm{N}=190)$. Size classes were $\leq 4 \mathrm{~cm}, 4.1-10 \mathrm{~cm}$ and $>10 \mathrm{~cm}$ diameter, and values shown are percentage of the total number of interactions

bers of interacting colonies were found (360 in St. John and 402 in Jamaica), although the area surveyed differed between islands. The most common interactions were between Agaricia and algae, followed by Agaricia and congenerics (Fig. 1). Overall, the frequency of interactions among Agaricia (all size classes) and other taxa (algae, Agaricia, other scleractinians, and invertebrates) was dependent on site $(G=34.698$, df $=3$, p $\leq$ 0.001). Unplanned comparisons showed this was a result of the higher frequency of congeneric interactions in Jamaica (190 cases) compared to St. John (78 cases), as well as the high frequency of Agaricia-invertebrates interactions in St. John (Fig. 1). Although not statistically significant, interactions among Agaricia

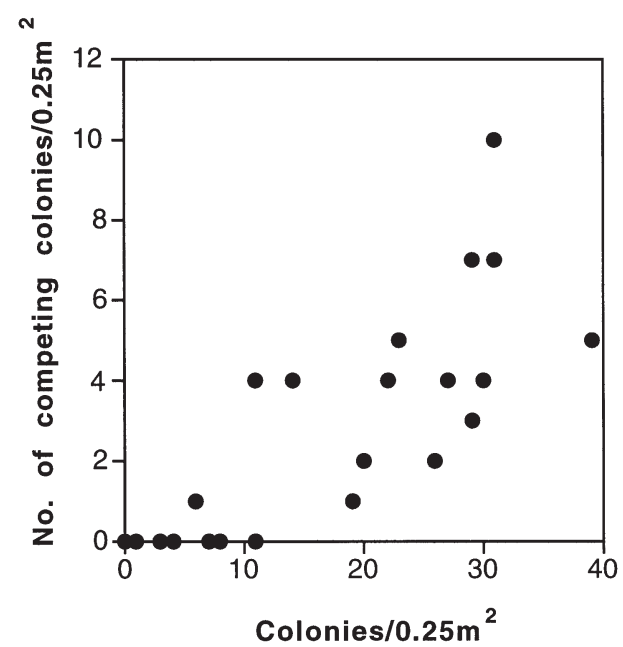

Fig. 3. Relationship between the density (no. of colonies/0.25 $\mathrm{m}^{2}$ ) of small Agaricia $(\leq 4 \mathrm{~cm})$ and the frequency of encounters (no. of competing colonies $/ 0.25 \mathrm{~m}^{2}$ ) for the same size class in Jamaica (10 $\mathrm{m}$ depth). There was a significant correlation between density and number of competing colonies $(r=0.783$,

$$
\mathrm{df}=21, \mathrm{p}<0.001)
$$

and other scleractinians were more frequent in Jamaica than St. John, and interactions of Agaricia with algae were more common in St. John than Jamaica.

The frequency of congeneric encounters for Agaricia did not vary significantly between sites or size classes ( $G=0.236$, df =2, p = 0.889) (Fig. 2), even though there were large differences in Agaricia density between sites. Congeneric interactions were, however, $\geq 4$-fold more common for small (68\%), compared to both medium $(17 \%)$ and large $(15 \%)$ colonies at both sites (Fig. 2). The density of Agaricia (no. of colonies/ $0.25 \mathrm{~m}^{2}$ ) and the frequency of congeneric encounters were significantly and positively correlated $(\mathrm{r}=0.783$, df $=21, p<0.001$, Fig. 3), as were density and topographic complexity ( $\mathrm{r}=0.560$, df $=21, \mathrm{p}<0.010$, Fig. 4) Therefore as the density of small Agaricia increases, the frequency of encounters increases, and this relationship is accentuated by high TC.

\section{Relationship between colony size and competitive outcome}

The relationship between size asymmetry and competitive outcome for small Agaricia (pooled between sites, $\mathrm{N}=36$ observations) was significant (logistic regression; $\chi^{2}=12.46$, df $=1, \mathrm{p} \leq 0.001$ ), with dominance being associated with greater size. Thus, based on an analysis of coral-coral interactions for which the outcome was readily apparent from overgrowth of one colony by another, dominant colonies frequently (94\% of the interactions) were bigger than subordinate colonies (Fig. 5).

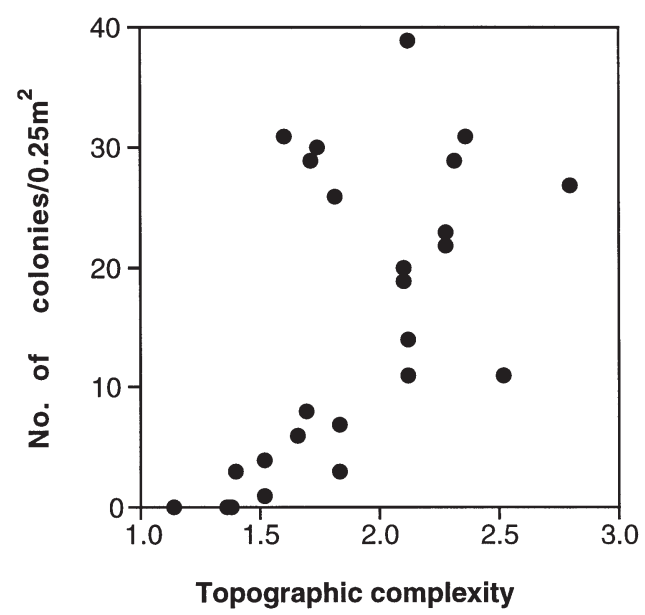

Fig. 4. Relationship between topographic complexity (TC, see text for details) and density of small Agaricia $(\leq 4 \mathrm{~cm})$ in Jamaica (10 $\mathrm{m}$ depth). There was a significant correlation between TC and density $(\mathrm{r}=0.560, \mathrm{df}=21, \mathrm{p}=0.007)$ 


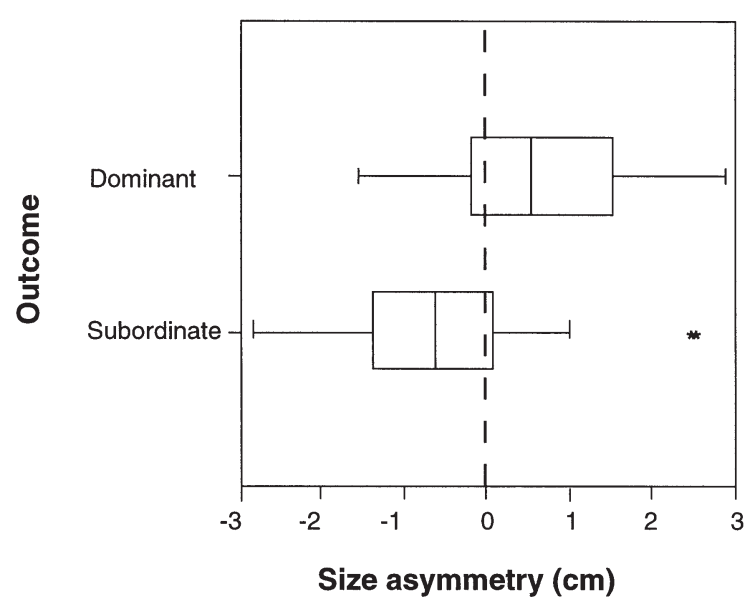

Fig. 5. Relationship between size asymmetry and the outcome of congeneric competition for small $(\leq 4 \mathrm{~cm})$ Agaricia, pooled between sites (St. John and Jamaica; $\mathrm{N}=36$ ). There was a significant (Logistic Regression; $\chi^{2}=12.46, \mathrm{df}=1, \mathrm{p} \leq 0.001$ ) and positive relationship between size asymmetry and outcome, so that dominant colonies generally were larger than subordinate colonies. Box plot shows medians (middle vertical lines inside the interquartile range boxes), interquartile ranges (length of the boxes), the horizontal lines outside the interquartile boxes are observations within 1.5 interquartile ranges. * = observations that are more than $1.5 \times$ (interquartile range) from the median. Refer to text for further details

\section{DISCUSSION}

This study was carried out to determine the relative importance of competition among small Agaricia, and to document the role of colony size asymmetry in determining the outcome of congeneric competition. Colonies of Agaricia, regardless of size, were engaged in competition with congenerics more often than any kind of interaction, other than with algae (macroalgae and algal turf combined). This relationship was found in St. John and Jamaica, suggesting that it is common in at least 2 locations in the Caribbean which differ in densities of Agaricia. In addition, congeneric competition was more common among the smallest $(\leq 4 \mathrm{~cm}$ diameter) size class of Agaricia, particularly in areas of high topographic complexity where algal turf was minimal and small Agaricia were abundant. Although, the density of Agaricia was almost 84-fold higher in Jamaica than in St. John, the frequency of congeneric interactions among small Agaricia was similar in both places, probably because small Agaricia were aggregated in cryptic microhabitats regardless of location. These results underscore the potentially important synergism between biological events (e.g., aggregated settlement; Goreau et al. 1981, Carlon \& Olson 1993) and physical factors (e.g., topographic complexity;
Carleton \& Sammarco 1987) in intensifying competition among young Agaricia. The positive relationship between size asymmetry and competitive outcome for small Agaricia agrees with previous studies with bryozoans (Buss 1980, Padilla et al. 1996) and at least one other scleractinian (Stylophora pistillata, Rinkevich \& Loya 1983). It is likely that this result (that large size is associated with competitive dominance) has general application to other sessile, colonial taxa in the marine environment.

Competitive interactions among colonies of Agaricia were relatively more frequent in small compared to large colonies. Although this effect was large (Fig. 2), it was not significant in the $G$-test of independence because an intrinsic hypothesis was used to generate expected values (sensu Sokal \& Rohlf 1995) that were similar between sites and among size classes. One reason for the high frequency of congeneric encounters among small ( $\leq 4 \mathrm{~cm}$ diameter) compared to large ( $>4 \mathrm{~cm}$ diameter) Agaricia, may be a change in the biological factors affecting colonies as they grow. For instance, congeneric competition might be replaced by interspecific competition (Lang \& Chornesky 1990) as colonies become larger and grow out of the cryptic habitats where the larvae prefer to settle (Carlon \& Olson 1993). In such cryptic locations, the densities of small Agaricia can be very high (Lewis 1974, Smith 1997, this study), and the resulting acute space limitation promotes congeneric encounters. Topographically complex reefs have more spatial refuges for Agaricia larvae to settle in (Carleton \& Sammarco 1987), and this, in turn, facilitates congeneric interactions. Not all scleractinians display aggregated settlement, but there are other conspicuous examples of this strategy, including Favia fragum and Porites porites, in the Caribbean (Goreau et al. 1981, Carlon \& Olson 1993), and Goniastrea aspera and Pocillopora damicornis in the Pacific (Birkeland et al. 1981, Babcock 1984). For these, and other scleractinians that display aggregated settlement, intraspecific competition at early life history stages may be an important factor affecting population structure (Sammarco 1980, Hughes 1985). There is growing recognition of the importance to coral demographics of understanding the sources of mortality among newly recruiting corals (Hughes \& Tanner 2000), and here we show that congeneric competition at early life history stages may be one such factor.

The density of small Agaricia increases with topographic complexity on a reef at Dairy Bull, Jamaica, and this increases the number of encounters among small colonies. Such encounters likely develop into competitive interactions, since overgrowth (a common outcome of competition, Buss 1980) was widespread, and fusion was rare $(<0.5 \%$ of such encounters). 
Fusion among conspecifics occurs in many colonial organisms, including corals (Hidaka 1985), hydroids (Shenk \& Buss 1991) and colonial ascidians (Sabbadin \& Astorri 1988). However, the ability to fuse can vary with age in hydroids (Shenk \& Buss 1991) and scleractinians (Hidaka 1985, Frank et al. 1997), with the highest potential for fusion occurring immediately after settlement (Shenk \& Buss 1991, Frank et al. 1997). Newly settled Agaricia (i.e., spat) were not included in the present analysis as it is impossible to resolve such small objects (ca $<2 \mathrm{~mm}$ diameter) by eye in the field. Thus, it is possible that fusion occurs among Agaricia spat, but further research will be required to evaluate the likelihood of such events. Based on the low rates of fusion we observed among Agaricia, together with the lack of evidence of fusion among A. humilis (Raimondi \& Morse 2000), it is likely that fusion does not result in a biologically significant loss of colonies in this genus. Regardless of the possibilities for fusion, the present results demonstrate that congeneric competition has a strong potential to affect the density of small Agaricia.

To understand how (if at all) congeneric competition influences the population structure of Agaricia, it is important to know how a colony becomes dominant (as opposed to subordinate). This is because subordinance can lead to partial mortality (Buss 1986) and increased susceptibility to further injuries and death (Hughes 1984). This, in turn, can affect population structure by decreasing the number of colonies attaining size-dependent sexual maturity (Hughes \& Jackson 1985). Two possible factors determining competitive outcome may be: (1) the availability of energy and the ability to allocate it towards competition (Oren et al. 1997), and (2) limited regenerative capabilities in colonies with large lesions relative to their small size (Rinkevich 1996). The energy hypothesis assumes that the mechanisms of competition (e.g., sweeper tentacles and nematocysts) are energetically costly to produce, that energy is a limiting resource, and that energy resources can be translocated across a competing colony. The limited regeneration hypothesis assumes that stem cells, which play a role in tissue regeneration, can be a limited resource in anthozoans (Rinkevich 1996). If correct, then the importance of stem cell limitation will be inversely related to colony size, because small colonies have less tissue to support the repair of lesions. The assumptions of the energy hypothesis hold true for several organisms (Miles et al. 1995, Oren et al. 1997), but they have yet to be addressed for Agaricia. Conversely, there are no experimental tests of stem cell limitation of regeneration in anthozoans. Before further research is completed to determine which hypothesis best accounts for the present results (i.e.,
Fig. 5), manipulative experiments first are required to establish a cause-and-effect relationship between colony size and competitive outcome. The mensurative experiments employed in the present study cannot be used to infer a cause-and-effect relationship (sensu Buss 1990) and, indeed, several alternative hypotheses could account for our results. For example, colony size may be a consequence of congeneric competition (rather than a determinant of outcome), with larger size occurring after dominance is achieved. Dominance itself might be determined by factors other than size at first encounter, including angle of contact between competing colonies (Buss 1981, Romano 1990), ambient flow conditions (Genin et al. 1994), or random factors (e.g., storms or predation; Connell 1978, Hughes 1989) coincident with the contact between colonies.

Although further research is required, we believe that disparities in growth rate-interpreted broadly to include mass deposition, linear extension and skeletal morphology - provide the most parsimonious explanation for competitive outcomes between Agaricia colonies. All aspects of coral growth show a high degree of intraspecific variation (Harrison \& Wallace 1990, Hall \& Hughes 1996, Bruno \& Edmunds 1997), and rapid growth and directional change can provide powerful mechanisms of competitive dominance, at least in adult corals (Romano 1990). Thus, it is likely that small colonies of Agaricia that have intrinsically fast growth, or enhanced ability to change morphology, may be able to overgrow (i.e., out compete) colonies with slower growth and/or reduced ability for morphological change. Preliminary experiments support the role of rapid linear growth in determining competitive dominance among small Agaricia (Zilberberg 2001).

Acknowledgements. This manuscript was submitted in partial fulfillment of the MS degree to C.Z. at California State University, Northridge. Many thanks to R. C. Carpenter, S. R. Dudgeon, and P. S. Wilson for advice, comments and support given at all stages of this work. Thanks to C. Grippaldi and V. Powell for making our St. John visits enjoyable, and to C. S. Rogers for support through the Coral Reef Assessment Program of the V.I. National Park. We thank M. Haley for providing a pleasurable stay at the Discovery Bay Marine Laboratory (DBML) in Jamaica. C. Zilberberg is indebted to R. Kemp and many friends for help in the field, and to R. L. Habeeb, H. L. Stewart, and S. V. Vollmer for help and encouragement through all phases of the work. Comments from J. F. Bruno and 2 anonymous reviewers improved early drafts of this manuscript. Financial support was made available through the Coral Reef Assessment Program of the V.I. National Park (to P.J.E.), the East/West Marine Biology Program of Northeastern University, and the Graduate Research and International Program at CSUN (to C.Z., grant \#323430932). This research was completed under permits \#98-07 and 99-06 to P.J.E. in St. John, and is DBML contribution \#764. 


\section{LITERATURE CITED}

Ayre DJ, Grosberg RK (1995) Aggression, habituation, and clonal coexistence in the sea anemone Anthopleura elegantissima. Am Nat 146:427-453

Babcock RC (1984) Reproduction and distribution of two species of Goniastrea (Scleractinia) from the Great Barrier Reef Province. Coral Reefs 2:187-195

Bak RPM, Engel MS (1979) Distribution, abundance and survival of juvenile hermatypic corals (Scleractinia) and the importance of life history strategies in the parent coral community. Mar Biol 54:341-352

Bak RPM, Meesters EH (1999) Population structure as a response of coral communities to global change. Am Zool 39:56-65

Birkeland C, Rowley D, Randall RH (1981) Coral recruitment patterns at Guam. Proc 4th Int Coral Reef Symp 2:339-344

Bruno JF, Edmunds PJ (1997) Clonal variation for phenotypic plasticity in the coral Madracis mirabilis. Ecology 78: 2177-2190

Buss LW (1980) Competitive intransitivity and size-frequency distributions of interacting populations. Proc Natl Acad Sci USA 77:5355-5359

Buss LW (1981) Mechanisms of competition between Onychocella alula (Hastings) and Antropora tincta (Hastings) on an Eastern Pacific rocky shore line. In: Larwood GP, Nielsen C (eds) Recent and fossil Bryozoa. Olsen and Olsen, Fredensborg, p 39-49

Buss LW (1986) Competition and community organization on hard surfaces in the sea. In: Case T, Diamond $\mathrm{J}$ (eds) Community ecology. Harper and Row, New York, p 517-536

Buss LW (1990) Competition within and between encrusting clonal invertebrates. TREE 5:352-356

Buss LW, Jackson JBC (1979) Competitive networks: nontransitive competitive relationships in cryptic coral reef environments. Am Nat 113:223-234

Carleton JH, Sammarco PW (1987) Effects of substratum irregularity on success of coral settlement: quantification by comparative geomorphological techniques. Bull Mar Sci 40:85-98

Carlon DB, Olson RR (1993) Larval dispersal distance as an explanation for adult spatial pattern in two Caribbean reef corals. J Exp Mar Biol Ecol 173:247-263

Chornesky EA (1983) Induced development of sweeper tentacles on the reef coral Agaricia agaricites: a response to direct competition. Biol Bull 165:569-581

Connell JH (1978) Diversity in tropical rain forests and coral reefs. Science 199:1302-1310

Connell JH, Hughes TP, Wallace CC (1997) A 30-year study of coral abundance, recruitment, and disturbance at several scales in space and time. Ecol Monogr 67:461-488

Dunstan PK, Johnson CR (1998) Spatio-temporal variation in coral recruitment at different scales on Heron Reef, southern Great Barrier Reef. Coral Reefs 17:71-81

Edmunds PJ (2000) Patterns in the distribution of juvenile corals and coral reef community structure in St. John, US Virgin Islands. Mar Ecol Prog Ser 202:113-124

Edmunds PJ, Bruno JF (1996) The importance of sampling scale in ecology: Kilometer-wide variation in coral reef communities. Mar Ecol Prog Ser 143:165-171

Edmunds PJ, Carpenter RC (2001) Recovery of Diadema reduces macroalgal cover and increases abundance of juvenile corals on a Caribbean reef. Proc Natl Acad Sci USA 98:5067-5071

Frank U, Oren U, Loya Y, Rinkevich B (1997) Alloimmune maturation in the coral Stylophora pistillata is achieved through three distinctive stages, 4 months post-metamorphosis. Proc R Soc Lond 264:99-104

Genin A, Karp L, Miroz A (1994) Effects of flow on competitive superiority in scleractinian corals. Limnol Oceanogr 39:913-924

Goreau NI, Goreau TJ, Raymond LH (1981) Settling, survivorship and spatial aggregation in planulae and juveniles of the coral Porites porites (Pallas). Bull Mar Sci 31:424-435

Hall VR, Hughes TP (1996) Reproductive strategies of modular organisms: Comparative studies of reef-building corals. Ecology 77:950-963

Harrison PL, Wallace CC (1990) Reproduction, dispersal and recruitment of scleractinian corals. In: Dubinsky Z (ed) Ecosystems of the world, Coral Reefs. Elsevier, New York, p 133-207

Hidaka M (1985) Tissue compatibility between colonies and between newly settled larvae of Pocillopora damicornis. Coral Reefs 4:111-116

Hidaka M, Yamazato K (1984) Intraspecific interactions in a scleractinian coral, Galaxea fascicularis: induced formation of sweeper tentacles. Coral Reefs 3:77-85

Highsmith RC (1982) Reproduction by fragmentation in corals. Mar Ecol Prog Ser 7:207-226

Hughes TP (1984) Population dynamics based on individual size rather than age: a general model with a coral reef example. Am Nat 123:778-795

Hughes TP (1985) Life histories and population dynamics of early successional corals. Proc 5th Int Coral Reef Symp 4: 101-106

Hughes TP (1989) Community structure and diversity of coral reefs: the role of history. Ecology 70:275-279

Hughes TP, Jackson JBC (1980) Do corals lie about their age? Some demographic consequences of partial mortality, fission and fusion. Science 209:713-715

Hughes TP, Jackson JBC (1985) Population dynamics and life histories of foliaceous corals. Ecol Monogr 55:141-166

Hughes TP, Tanner JE (2000) Recruitment failure, life histories and long-term decline of Caribbean corals. Ecology 81:2250-2263

Jackson JBC, Buss L (1975) Allelopathy and spatial competition among coral reef invertebrates. Proc Natl Acad Sci USA 72:5160-5163

Lang JC (1973) Interspecific aggression by scleractinian corals. 2. Why the race is not only to the swift. Bull Mar Sci 23:260-279

Lang JC, Chornesky EA (1990) Competition between scleractinian reef corals - a review of mechanisms and effects. In: Dubinsky Z (ed) Ecosystems of the world, Coral Reefs, p 209-252

Lewis JB (1974) Settlement and growth factors influencing the contagious distribution of some Atlantic reef corals. Proc 2nd Int Coral Reef Symp 2:201-206

Menge BA (1976) Organization of the New England rocky intertidal community: role of predation, competition, and environmental heterogeneity. Ecol Monogr 46:355-393

Miles JS, Harvell CD, Griggs CM, Eisner S (1995) Resource translocation in a marine bryozoan: quantification and visualization of ${ }^{14} \mathrm{C}$ and ${ }^{35} \mathrm{~S}$. Mar Biol 122:439-445

Morse DE, Hooker N, Morse ANC, Jensen RA (1988) Control of larval metamorphosis and recruitment of sympatric agariciid corals. J Exp Mar Biol Ecol 116:193-217

Oren U, Rinkevich B, Loya Y (1997) Oriented intra-colonial transport of ${ }^{14} \mathrm{C}$ labeled materials during coral regeneration. Mar Ecol Prog Ser 161:117-122

Padilla DK, Harvell CD, Marks J, Helmuth B (1996) Inducible aggression and intraspecific competition for space in a 
marine bryozoan, Membranipora membranacea. Limnol Oceanogr 41:505-512

Raimondi PT, Morse ANC (2000) The consequences of complex larval behavior in a coral. Ecology 81:3193-3211

Rinkevich B (1996) Do reproduction and regeneration in damaged corals compete for energy allocation? Mar Ecol Prog Ser 143:297-302

Rinkevich B, Loya Y (1983) Intraspecific competitive networks in the Red Sea coral Stylophora pistillata. Coral Reefs 1: 161-172

Rogers CS, Fitz III HC, Gilnack M, Beets J, Hardim J (1984) Scleractinian coral recruitment patterns at Salt River Submarine Canyon, St. Croix, U.S. Virgin Islands. Coral Reefs 3:69-76

Romano SL (1990) Long-term effects of interspecific aggression on growth of the reef-building corals Cyphastrea ocellina (Dana) and Pocillopora damicornis (Linnaeus). J Exp Mar Biol Ecol 140:135-146

Sabbadin A, Astorri C (1988) Chimeras and histocompatibility in the colonial ascidian Botryllus schlosseri. Dev Comp Immunol 12:737-747

Sammarco PW (1980) Diadema and its relationship to coral spat mortality: grazing, competition, and biological disturbance. J Exp Mar Biol Ecol 45:245-272

Sebens KP (1982) Competition for space: growth rate, reproductive output, and escape in size. Am Nat 120:189-197

Shenk MA, Buss LW (1991) Ontogenetic changes in fusibility in the colonial hydroid Hydractinia symbiolongicarpus. J Exp Zool 257:80-86

Sheppard CRC (1979) Interspecific aggression between reef corals with reference to their distribution. Mar Ecol Prog Ser 1:237-247

Editorial responsibility: Charles Birkeland (Contributing Editor), Honolulu, Hawaii, USA
Sheppard CRC (1980) Coral cover, zonation and diversity on reef slopes of Chagos Atolls and population structures of the major species. Mar Ecol Prog Ser 2:193-205

Smith SR (1997) Patterns of coral settlement, recruitment and juvenile mortality with depth at Conch Reef, Florida. Proc 8th Int Coral Reef Symp 2:1197-1202

Snell TW (1979) Intraspecific competition and population structure in rotifers. Ecology 60:494-502

Sokal RR, Rohlf FJ (1995) Biometry. The principles and practice of statistics in biological research, 3rd edn. WH Freeman \& Company, New York

Steneck RS, Watling L (1982) Feeding capabilities and limitation of herbivorous molluscs: a functional group approach. Mar Biol 68:229-319

Van Moorsel GWNM (1983) Reproductive strategies in two closely related stony corals (Agaricia, Scleractinia). Mar Ecol Prog Ser 13:273-283

Van Moorsel GWNM (1985) Disturbance and growth of juvenile corals (Agaricia humilis and Agaricia agaricites, Scleractinia) in natural habitats on the reef in Curaçao. Mar Ecol Prog Ser 24:99-112

Wallace CC (1985) Seasonal peaks and annual fluctuations in recruitment of juvenile scleractinian corals. Mar Ecol Prog Ser 21:289-298

Yund PO (1991) Natural selection on hydroid colony morphology by intraspecific competition. Evolution 45: $1564-1573$

Zilberberg C (2001) The importance of competition among small Agaricia in shallow Caribbean reefs and possible factors determining competitive outcome. Masters thesis, California State University, Northridge

Submitted: February 12, 2001; Accepted: May 18, 2001 Proofs received from author(s): October 5, 2001 